\title{
Article \\ Influence of Root Canal Fillings on Alveolar Bone Crest Level-An Observational Cross Sectional CBCT Analysis
}

\author{
Marco Lubrich ${ }^{1}$, David Donnermeyer ${ }^{2}\left(\mathbb{D}\right.$, Edgar Schäfer ${ }^{3}(\mathbb{D})$ and Sebastian Bürklein ${ }^{3, *} \mathbb{( D}$ \\ 1 Dental Practice, Dres. Pawlak and Colleagues, Lothringer Str. 36a, 44805 Bochum, Germany; \\ lubrich.marco@gmail.com \\ 2 Department of Periodontology and Operative Dentistry, Westphalian Wilhelms-University, \\ Albert-Schweitzer-Campus 1, Building W 30, 48149 Münster, Germany; david.donnermeyer@ukmuenster.de \\ 3 Central Interdisciplinary Ambulance in the School of Dentistry, University of Münster, \\ Albert-Schweitzer-Campus 1, Building W 30, 48149 Münster, Germany; eschaef@uni-muenster.de \\ * Correspondence: sebastian.buerklein@ukmuenster.de
}

Citation: Lubrich, M.; Donnermeyer, D.; Schäfer, E.; Bürklein, S. Influence of Root Canal Fillings on Alveolar Bone Crest Level-An Observational Cross Sectional CBCT Analysis. Appl. Sci. 2021, 11, 8583. https://doi.org/ 10.3390/app11188583

Academic Editor: Seok Woo Chang

Received: 21 August 2021

Accepted: 13 September 2021

Published: 15 September 2021

Publisher's Note: MDPI stays neutra with regard to jurisdictional claims in published maps and institutional affiliations.

Copyright: (c) 2021 by the authors. Licensee MDPI, Basel, Switzerland. This article is an open access article distributed under the terms and conditions of the Creative Commons Attribution (CC BY) license (https:/ / creativecommons.org/licenses/by/ $4.0 /)$.

\begin{abstract}
The aim of this study was to compare the alveolar bone crest (ABC) level of root canal filled (RCF) teeth without apical periodontitis with corresponding non-filled teeth in the same individual using three-dimensionally cone-beam computed tomography (CBCT) data. Two hundred and thirty-five matching pairs of RCF teeth and corresponding teeth without RCF were selected from a pool of 580 random CBCT-images (voxel size 160-200 $\mu \mathrm{m}$ ). Teeth with apical periodontitis, perio-endodontic lesions or surgical endodontic treatment were excluded. The distance between the cemento-enamel-junction (CEJ) and the ABC was assessed centrally mesial, distal, palatal/lingual and buccal at each tooth ( $\sum 1880$ measuring points) in a standardized manner. Topographic, gender, and age-related relationships were also noted. Data were analyzed using the Kruskal-Wallis-test. The ABC-level between RCF teeth $(2.64 \pm 1.25 \mathrm{~mm})$ and teeth without RCF $(2.61 \pm 1.16 \mathrm{~mm})$ did not differ significantly $(p>0.05)$. No differences concerning localization (maxilla/mandible, tooth type) and gender $(p>0.05)$ occurred. Overall, ABC-level in the maxilla $(2.74 \pm 1.48 \mathrm{~mm})$ was significantly lower $(p<0.001)$ compared to mandibular teeth $(2.50 \pm 1.41 \mathrm{~mm})$. Patients $>41$ years had significantly lower ABC-levels than younger patients $(p<0.05)$. Men showed a reduced bone level compared to women $(p<0.05)$. In conclusion, RCF teeth are identical to their non-RCF counterparts, at least in terms of crestal bone level, regardless of the location or type of tooth and the gender of the patient. Thus, root canal treatment is an essential pillar for long-term tooth preservation.
\end{abstract}

Keywords: alveolar process/diagnostic imaging; bone; cone beam volume tomography; root canal therapy; tooth root/diagnostic imaging; tooth; nonvital/diagnostic imaging; pathology

\section{Introduction}

The absence of the pulp as a sensory and nourishing organ/tissue may negatively influence long-term outcome of teeth undergone root canal treatment, because the endodontic tissue and the periodontium are physiologically in connection via the apical foramen, accessory or furcation canals and dentinal tubules [1]. Additionally, endodontium and periodontium may harbor similar bacterial species and bacteria, their metabolites and toxins that remain in the tubules, as well as the materials used for root canal treatment, could affect the periodontium [2-4].

The current available literature mainly based on two-dimensional radiographic and clinical examination shows almost consistently no correlation between bone loss/level and/or an impact on the periodontium and the endodontic status [5-8].

Only one study showed that root canal-filled (RCF) teeth in patients suffering from periodontitis exhibit significantly increased bone loss compared to their untreated contralateral counterparts [9]. In general, periapical pathologies seem to favor periodontal destruction/bone loss in periodontitis prone patients [10]. In addition, a more frequent correlation 
of apical and marginal periodontitis has been described-independent of patient-related factors such as age, number of remaining teeth, relative frequency of root-filled teeth and smoking habits [11].

According to the common radiographic projections (periapical, bite-wing and panoramic radiographs) for the analysis of periodontal tissues, all existing studies concerning alveolar bone loss/periodontal attachment loss in root canal treated teeth rely on two-dimensional radiographs evaluating only the interproximal bone level by measuring one mesial and one distal measuring point per tooth. Hence, no information concerning the oral and buccal aspect of bone level are available up to now.

Cone-beam computed tomography (CBCT) allows a three-dimensional analysis of the teeth and the surrounding, especially bony structures free from superimposition [12,13]. The diagnosis of periodontal diseases and bony defects offers a sensitivity between 80-100\% [14-17]. Therefore, CBCT data allow a more precise assessment of the marginal bone level than two-dimensional radiographs.

Thus, the present cross-sectional observational comparative study in a German population solely aimed to compare the alveolar bone crest (ABC) level of root canal filled teeth without apical periodontitis and the corresponding non-filled teeth in the same individual, irrespective their periodontal status, using 3D radiographs (CBCT) based on four measuring points at each tooth - centrally mesial, distal, buccal and palatal/lingual, respectively.

The null-hypothesis was that bone levels around root canal filled teeth do not differ from those of untreated teeth.

\section{Materials and Methods}

The study followed the "Strengthening the Reporting of Observational studies in Epidemiology" (STROBE) checklist (see Supplementary Materials).

\subsection{Sample Size Calculation}

Prior to examination, two examiners (S.B., M.L.) independently assessed and analyzed the alveolar bone crest level in a sample of 15 patients offering 25 "matching pairs" of one non-root canal filled (n-RCF) and one corresponding RCF tooth, following the same protocol as in the main study (four measuring points: mesial, distal, lingual/palatal and buccal) for calibration purposes and sample size calculation. The preliminary analysis by the means and standard deviations of the groups and correlation between the groups revealed a small effect size of 0.12 . Calculation resulted in a sample size of at least 425 (G-Power, Heinrich-Heine University Düsseldorf, Germany) to achieve a power of 0.80 to obtain differences of means (matching pairs) in two dependent groups. Thus, 470 teeth with 1880 measuring points were evaluated in the present study ( 235 matching pairs).

\subsection{Patient Population}

Randomly selected CBCT data of a 5-year period (2008 to 2013) of 580 German individuals were evaluated concerning the inclusion criteria. For this purpose, all CBCT data were analyzed consecutively based on their acquisition date starting on 1 March 2008, until the sample size was reached. All the CBCT examinations were performed for various indications (e.g., implant planning or surgical treatment planning) not related to the present study.

\subsection{Inclusion Criteria}

The radiographs were screened for inclusion following these criteria:

- $\quad$ Adequate quality of CBCT data (no scattering or moving artefacts in the ROI)

- Presence of at least one root canal treated tooth (RCF) and a contralateral matching non-root canal treated tooth (n-RCF)

- Flush root canal filling (root canal should be filled to within $2 \mathrm{~mm}$ of the radiographic apex) [18] 
- Comparable restauration margins (if present) at or above the level of the cementoenamel junction (CEJ)

Teeth were excluded if the radiographs of a patient matched at least one of the following criteria:

- Incomplete assessability of the radiography

- Missing contralateral matching tooth

- Restoration margin below CEJ

- Apical periodontitis or lateral pathologies

- Interradicular osteolysis, bony defect

- Suspected perforation

- Suspected external resorption

- Inhomogeneous and/or insufficient root canal filling

- Apicoectomy

The inclusion and exclusion criteria were applied irrespective of any periodontal disease of the individuals. Thus, periodontally compromised patients were also included in the evaluation.

\subsection{Radiographic Examinations}

Full-size $(8 \times 8 \mathrm{~cm})$ CBCT (Planmeca ProMax 3D, Planmeca, Helsinki, Finland); voxel size 160 or $200 \mu \mathrm{m}$; KV (60-90), mA (1-14) and exposition time according to the patient's individual needs based on the diagnostics required.

\subsection{Evaluation of Radiographs}

The digital DICOM radiograph files were analyzed with Planmeca Romexis Viewer 5.1.0.R (Planmeca, Helsinki, Finland) on a calibrated diagnostic monitor (Acer B246HYL, Acer, Taipei, Taiwan) in a dark room with the monitor as the only light source.

All distances were measured in millimeters using the integrated distance-measuring tool of the Romexis Viewer in the 1:1 view.

\section{Definition of Anatomic and Radiographic Landmarks}

The included teeth were aligned precisely lingual/palatal-buccally and mesio-distally to ensure an identical position before measurement. Teeth were positioned to the corresponding axial, coronal and sagittal slices in the software program for a general validity and comparability of the measurements. All measurements were assessed parallel to the surface of the examined teeth (Figure 1).

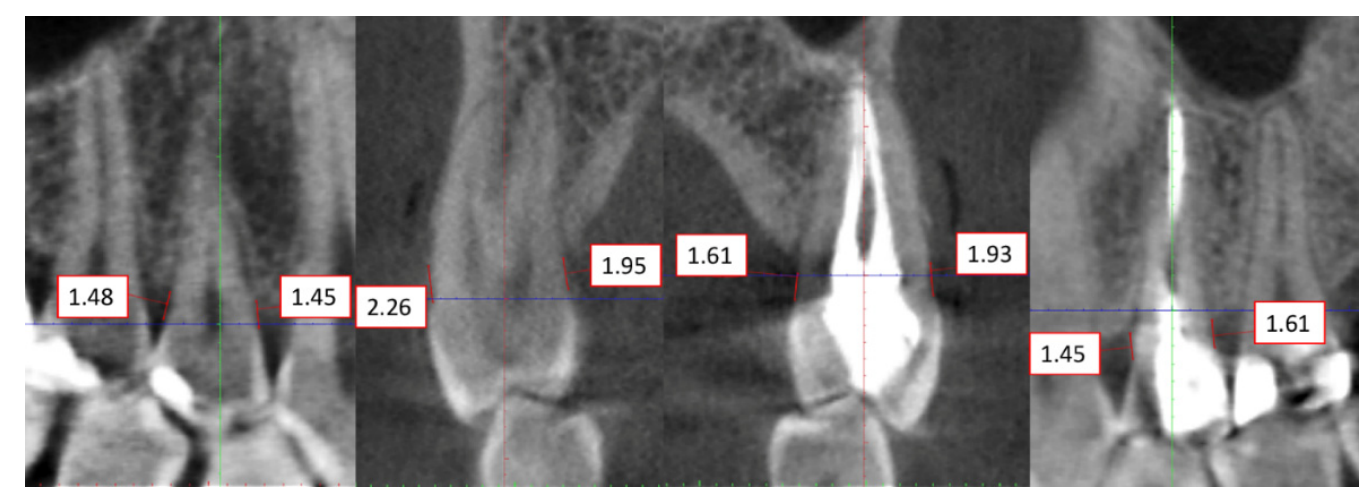

Figure 1. Exemplary measurements of the distance CEJ to the ABC (alveolar bone crest) in a matching pair (root canal treated tooth and corresponding non-treated tooth) in the same individual in the upper jaw. Alignment of the measurement along the palatal-buccal and mesio-distal central axis of the tooth.

The cemento-enamel-Junction (CEJ) represents the anatomic limit between the crown and the root surface. The CEJ is a static landmark that serves as an important anatomical 
site for measurement of probing pocket depth (PPD) and clinical attachment level (CAL) for both clinicians and academicians.

ABC-level: The ABC-level was defined as the most coronal point where the periodontal ligament space showed continuous width [19]. Distances between the CEJ and the ABC were measured for each tooth individually at four measuring points-centrally mesial, distal, lingual/palatal and buccal (Figure 1) as proposed by Hadzik et al. [20]. If the CEJ was not directly identifiable due to a restauration, the most apical margin of the restauration $(\mathrm{RM})$ in the affected region $(\mathrm{m}, \mathrm{d}, \mathrm{l} / \mathrm{p}, \mathrm{b})$ was used as a reference of the included teeth.

\subsection{Data Analysis}

Two examiners with certified experience in CBCT analysis independently screened 580 three-dimensional CBCT files in DICOM $(. \mathrm{dcm})$ format for matching pairs (RCF tooth with contralateral $\mathrm{n}-\mathrm{RCF}$ tooth) of teeth that met the inclusion criteria from March to June 2019. To prevent fatigue of the observers, the examinations were limited to a maximum of eight per day.

Both examiners measured all teeth separately according to the stated protocol. Mean values of both measurements served for statistical analysis (SPSS, IBM SPSS Statistics for Windows 26.0, IBM Corp., Armonk, NY, USA). Kolmogorov-Smirnov and Shapiro-Wilk tests revealed that the data were not normally distributed. Therefore, the Kruskal-Wallis test served for statistical analysis. The level of significance was set at 0.05 . Regression analysis was performed to determine the strength of the relationship between the identified variables.

\section{Results}

Screening process of the CBCT data identified 235 matching pairs of RCF teeth and their corresponding healthy counterparts ( 82 molars, 100 premolars, and 53 anterior teeth) resulting in 470 teeth and offering a total of 1880 measuring points. In the total data set, 73 additional matching pairs were found that did not meet the inclusion criteria. Thus, the exclusion rate was $23.7 \%$. The age of the 235 included patients ( 94 men, 141 women) varied from 20 years to 79 years $($ mean $=50.21 \pm 11.10)$.

\subsection{Calibration of the Two Examiners}

The inter-rater reliability (Cohens Kappa " $k$ ") in the main study was 0.919 and the mean overall difference between both examiners was less than $0.2 \mathrm{~mm}$. Means of both observers served for evaluation.

\subsection{Alveolar Bone Crest Level (RCF Versus Non-RCF Teeth)}

A total of 940 periodontal measuring points in each group were analyzed for both groups, RCF and n-RCF. No statistically significant differences $(p>0.05)$ were detected between teeth with root canal fillings $(2.64 \pm 1.25 \mathrm{~mm})$ and those without root canal fillings ( $2.61 \pm 1.16 \mathrm{~mm})$ (Table 1; Figure 2). The pairwise comparisons of both the mean values of each individual and of all individual measuring points show a marked scattering. A linear regression analysis reveals a gradient of 0.91 with a determination coefficient (R2) of 0.0001 indicating that a linear relationship cannot be assumed (Figure 2).

Tooth type (anterior teeth/premolars/molars) and location had no significant impact concerning bone loss when comparing root canal treated teeth to their unfilled counterparts $(p>0.05)$ (Tables 2 and 3). In addition, no gender or age-related differences were assessed between both groups concerning the influence of root canal treatment $(p>0.05)$ (Tables 4 and 5). 
Table 1. Distance CEJ-alveolar bone crest in the matching pairs with $95 \%$ confidence interval and the corresponding range; $\mathrm{CEJ}=$ cemento-enamel-junction; $\mathrm{RCF}=$ root canal filling; $\mathrm{CI}=$ confidence interval.

\begin{tabular}{cccccccc}
\hline & & \multicolumn{5}{c}{ Distance CEJ-Alveolar Bone Crest (mm) } \\
\cline { 3 - 7 } $\begin{array}{l}\text { No of } \\
\text { Teeth }\end{array}$ & \multirow{2}{*}{ RCF } & & Mesial & Distal & $\begin{array}{c}\text { Lingual/ } \\
\text { Palatal }\end{array}$ & Buccal & Mean \\
\hline \multirow{2}{2}{235} & yes & mean $\pm \mathrm{sd}$ & $2.51 \pm 1.09$ & $2.70 \pm 1.53$ & $2.73 \pm 1.22$ & $2.55 \pm 1.12$ & $2.64 \pm 1.24$ \\
& & CI 95\% & $2.37-2.65$ & $2.49-2.84$ & $2.58-2.89$ & $2.42-2.70$ & $2.51-2.77$ \\
& & range & 0.28 & 0.35 & 0.41 & 0.28 & 0.26 \\
\hline \multirow{2}{*}{235} & no & mean $\pm \mathrm{sd}$ & $2.52 \pm 1.22$ & $2.64 \pm 1.22$ & $2.70 \pm 1.10$ & $2.59 \pm 1.11$ & $2.61 \pm 1.16$ \\
& & CI 95\% & $2.37-2.68$ & $2.48-2.79$ & $2.55-2.84$ & $2.45-2.73$ & $2.49-2.73$ \\
& & range & 0.31 & 0.31 & 0.29 & 0.28 & 0.24 \\
\hline$\sum 470$ & $p$-value & & 0.789 & 0.601 & 0.776 & 0.555 & 0.810 \\
\hline
\end{tabular}

\section{[mm] pairwise mean ABC-levels of RCF and $\mathbf{n - R C F}$ teeth in each individual}

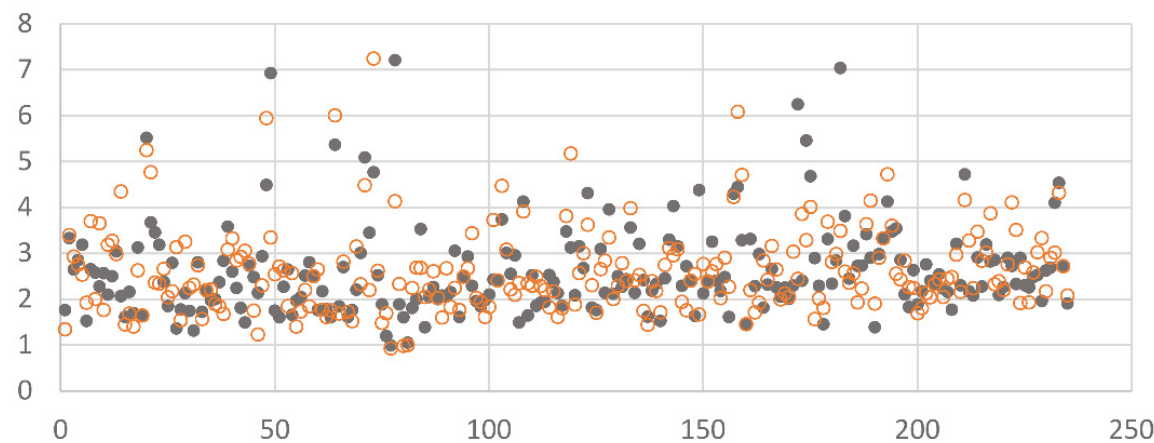

- RCF $\circ \mathrm{n}-\mathrm{RCF}$

[mm] comparison of all measuring points

RCF vs n-RCF teeth

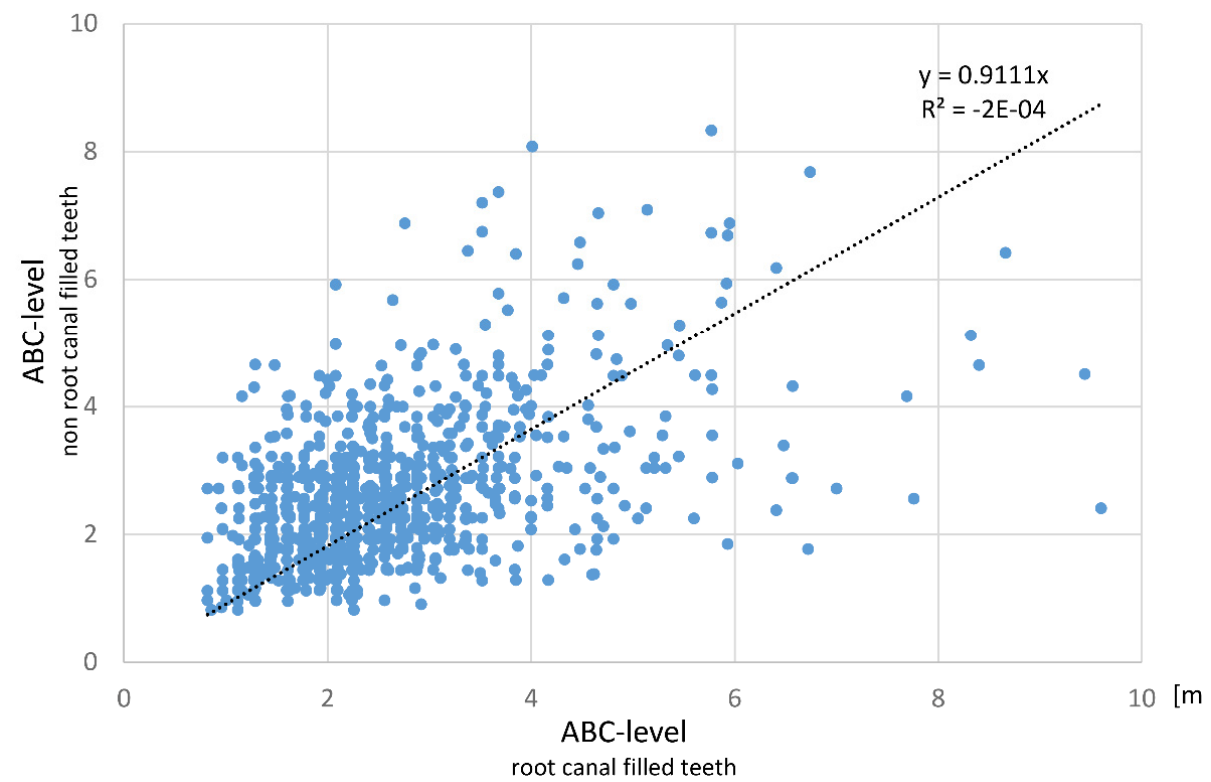

Figure 2. (Top) Pairwise comparison of the mean values of matching teeth in each individual concerning ABC-level of RCF and n-RCF teeth. (Bottom) Comparison of all measured values ( (RCF vs. n-RCF; mesial, distal, lingual/palatal, buccal $\left.=\sum 1180\right)$ between the CEJ and the ABC-level at each measuring point. 
Table 2. Distance CEJ-alveolar bone crest in the matching pairs related to the upper and lower jaw; both the differences within the jaws and those between the jaws are shown. $\mathrm{CEJ}=$ cemento-enamel-junction; $\mathrm{RCF}=$ root canal filling; $\mathrm{CI}=$ confidence interval [95\%].

\begin{tabular}{|c|c|c|c|c|c|c|c|c|c|}
\hline \multirow[b]{2}{*}{ Location } & \multirow[b]{2}{*}{$\begin{array}{l}\text { No of } \\
\text { Teeth }\end{array}$} & \multirow[b]{2}{*}{ RCF } & \multicolumn{7}{|c|}{ Distance CEJ-Alveolar Bone Crest (mm) } \\
\hline & & & & Mesial & Distal & $\begin{array}{c}\text { Lingual/ } \\
\text { Palatal }\end{array}$ & Buccal & Mean & $\begin{array}{l}\text { Pooled } \\
\text { Mean }\end{array}$ \\
\hline \multirow[t]{3}{*}{ upper jaw } & 118 & yes & mean \pm sd & $2.56 \pm 1.08$ & $2.73 \pm 1.34$ & $2.91 \pm 1.21$ & $2.67 \pm 1.10$ & $2.72 \pm 1.19$ & \\
\hline & & & CI 95\% & $2.36-2.75$ & $2.49-2.98$ & $2.68-3.13$ & $2.47-2.87$ & $2.54-2.89$ & \\
\hline & & & range & 0.39 & 0.49 & 0.45 & 0.40 & 0.35 & $2.74 \pm 1.22$ \\
\hline \multirow[t]{3}{*}{ upper jaw } & 118 & no & mean \pm sd & $2.63 \pm 1.27$ & $2.71 \pm 1.39$ & $2.93 \pm 1.20$ & $2.73 \pm 1.11$ & $2.76 \pm 1.25$ & \\
\hline & & & CI $95 \%$ & $2.40-2.86$ & $2.45-2.96$ & $2.72-3.16$ & $2.54-2.95$ & $2.58-2.94$ & \\
\hline & & & range & 0.46 & 0.49 & 0.44 & 0.41 & 0.36 & \\
\hline upper jaw & 236 & & $p$-value & 0.640 & 0.980 & 0.909 & 0.586 & 0.773 & \\
\hline \multirow[t]{3}{*}{ lower jaw } & 117 & yes & mean \pm sd & $2.46 \pm 1.09$ & $2.68 \pm 1.71$ & $2.56 \pm 1.21$ & $2.44 \pm 1.12$ & $2.55 \pm 1.31$ & \\
\hline & & & CI & $2.26-2.66$ & $2.33-2.86$ & $2.35-2.80$ & $2.25-2.67$ & $2.35-2.72$ & \\
\hline & & & range & 0.40 & 0.53 & 0.45 & 0.38 & 0.37 & $2.51 \pm 1.18$ \\
\hline \multirow[t]{3}{*}{ lower jaw } & 117 & no & mean \pm sd & $2.42 \pm 1.15$ & $2.56 \pm 1.03$ & $2.45 \pm 0.93$ & $2.43 \pm 1.08$ & $2.47 \pm 1.05$ & \\
\hline & & & CI & $2.20-2.63$ & $2.38-2.75$ & $2.28-2.62$ & $2.23-2.63$ & $2.31-2.62$ & \\
\hline & & & range & 0.43 & 0.37 & 0.34 & 0.40 & 0.31 & \\
\hline lower jaw & 234 & & $p$-value & 0.898 & 0.252 & 0.773 & 0.867 & 0.568 & \\
\hline total & 470 & & $p$-value & & & & & & $<0.0001$ \\
\hline
\end{tabular}

Table 3. Distance CEJ—alveolar bone crest in the matching pairs-related to tooth type; CEJ = cemento-enamel-junction; the table displays all measuring points of RCF and n-RCF teeth and the pooled data of the different tooth types with mean values, standard deviation and $95 \%$ confidence interval and the corresponding range of the values. $\mathrm{RCF}=\operatorname{root}$ canal filling; sd = standard deviation; $\mathrm{CI}=$ confidence interval.

\begin{tabular}{|c|c|c|c|c|c|c|c|c|}
\hline \multirow[b]{2}{*}{ Tooth Type } & \multirow[b]{2}{*}{ No of Teeth } & \multirow[b]{2}{*}{ RCF } & \multicolumn{6}{|c|}{ Distance CEJ-Alveolar Bone Crest (mm) } \\
\hline & & & & Mesial & Distal & $\begin{array}{c}\text { Lingual/ } \\
\text { Palatal }\end{array}$ & Buccal & $\begin{array}{l}\text { Pooled } \\
\text { Values }\end{array}$ \\
\hline \multirow[t]{3}{*}{ molar } & 82 & yes & mean \pm sd & $2.56 \pm 1.02$ & $2.78 \pm 1.16$ & $2,62 \pm 0.91$ & $2.52 \pm 0.89$ & $2.62 \pm 1.00$ \\
\hline & & & $95 \%$ CI & $2.33-2.78$ & $2.49-3.08$ & $2.43-2.82$ & $2.35-2.79$ & $2.46-2.79$ \\
\hline & & & range & 0.45 & 0.59 & 0.39 & 0.44 & 0.33 \\
\hline \multirow[t]{3}{*}{ molar } & 82 & no & mean \pm sd & $2.55 \pm 1.08$ & $2.71 \pm 1.03$ & $2.57 \pm 0.96$ & $2.48 \pm 0.88$ & $2.58 \pm 1.02$ \\
\hline & & & CI & $2.31-2.79$ & $2.49-2.92$ & $2.36-2.78$ & $2.28-2.67$ & $2.41-2.75$ \\
\hline & & & range & 0.48 & 0.43 & 0.42 & 0.39 & 0.36 \\
\hline molar & & & $p$-value & 0.896 & 0.725 & 0.802 & 0.837 & 0.870 \\
\hline \multirow[t]{3}{*}{ premolar } & 101 & yes & mean \pm sd & $2.56 \pm 1.11$ & $2.68 \pm 1.55$ & $2.96 \pm 1.50$ & $2.64 \pm 1.32$ & $2.71 \pm 1.37$ \\
\hline & & & 95\% CI & $2.34-2.78$ & $2.38-2.99$ & $2.66-3.26$ & $2.36-2.88$ & 2.47-2.94 \\
\hline & & & range & 0.44 & 0.61 & 0.60 & 0.42 & 0.47 \\
\hline \multirow[t]{3}{*}{ premolar } & 101 & no & mean \pm sd & $2.51 \pm 1.24$ & $2.64 \pm 1.42$ & $2.87 \pm 1.21$ & $2.70 \pm 1.23$ & $2.68 \pm 1.28$ \\
\hline & & & CI & $2.26-2.75$ & $2.36-2.92$ & $2.48-2.95$ & $2.46-2.94$ & $2.47-2.90$ \\
\hline & & & range & 0.49 & 0.56 & 0.47 & 0.48 & 0.43 \\
\hline \multirow{4}{*}{$\begin{array}{l}\text { premolar } \\
\text { anterior }\end{array}$} & & & $p$-value & 0.758 & 0.506 & 0.522 & 0.435 & 0.757 \\
\hline & 52 & yes & mean \pm sd & $2.55 \pm 1.17$ & $2.43 \pm 1.16$ & $2.68 \pm 1.14$ & $2.69 \pm 1.13$ & $2.59 \pm 1.12$ \\
\hline & & & $95 \%$ CI & $2.22-2.87$ & $2.12-2.75$ & $2.40-2.96$ & $2.37-3.00$ & $2.34-2.84$ \\
\hline & & & range & 0.55 & 0.63 & 0.56 & 0.63 & 0.50 \\
\hline \multirow[t]{3}{*}{ anterior } & 52 & no & mean \pm sd & $2.52 \pm 1.36$ & $2.42 \pm 1.11$ & $2.71 \pm 1.09$ & $2.62 \pm 1.15$ & $2.57 \pm 1.18$ \\
\hline & & & 95\% CI & $2.14-2.90$ & $2.13-2.76$ & 2.41-3.01 & $2.31-2.94$ & $2.34-2.81$ \\
\hline & & & range & 0.76 & 0.63 & 0.60 & 0.63 & 0.47 \\
\hline anterior & & & $p$-value & 0.648 & 0.834 & 0.727 & 0.559 & 0.916 \\
\hline
\end{tabular}


Table 4. Pooled age-related distances CEJ-alveolar bone crest in the matching pairs of RCF and n-RCF teeth. CI-interval, range, mean, sd, min and max. Different superscript letters indicate statistical significance $(p<0.05)$.

Pooled Age-Related Distances CEJ-Alveolar Bone Crest in the Matching Pairs of RCF and n-RCF Teeth

\begin{tabular}{|c|c|c|c|c|c|c|c|c|c|c|}
\hline Age & $\begin{array}{l}\text { No of } \\
\text { Teeth }\end{array}$ & $\begin{array}{l}\text { Measuring } \\
\text { Points }\end{array}$ & RCF & $\begin{array}{l}\text { Mean } \\
{[\mathrm{mm}]}\end{array}$ & $\begin{array}{c}\text { CI } \\
{[95 \%]}\end{array}$ & Range & $\begin{array}{l}\text { Pooled } \\
\text { Mean }\end{array}$ & sd & Min & Max \\
\hline $18-25$ & 24 & 96 & $\begin{array}{l}\text { yes } \\
\text { no }\end{array}$ & $\begin{array}{l}2.153 \\
2.147\end{array}$ & $\begin{array}{l}1.85-2.57 \\
1.83-2.36\end{array}$ & $\begin{array}{l}0.72 \\
0.53\end{array}$ & $2.15^{\mathrm{a}}$ & 0.72 & 0.96 & 3.3 \\
\hline $26-30$ & 28 & 112 & $\begin{array}{l}\text { yes } \\
\text { no }\end{array}$ & $\begin{array}{l}2.154 \\
2.149\end{array}$ & $\begin{array}{l}1.86-2.60 \\
1.84-2.33\end{array}$ & $\begin{array}{l}0.74 \\
0.49\end{array}$ & $2.15^{\mathrm{a}}$ & 0.73 & 1.13 & 5.32 \\
\hline $31-35$ & 30 & 120 & $\begin{array}{c}\text { yes } \\
\text { no }\end{array}$ & $\begin{array}{l}2.170 \\
2.165\end{array}$ & $\begin{array}{l}1.90-2.41 \\
1.80-2.48\end{array}$ & $\begin{array}{l}0.51 \\
0.68\end{array}$ & $2.17^{\mathrm{a}}$ & 0.96 & 1.06 & 4.98 \\
\hline $36-40$ & 48 & 192 & $\begin{array}{l}\text { yes } \\
\text { no }\end{array}$ & $\begin{array}{l}2.201 \\
2.200\end{array}$ & $\begin{array}{l}1.85-2.59 \\
1.80-2.35\end{array}$ & $\begin{array}{l}0.74 \\
0.55\end{array}$ & $2.20^{\mathrm{a}}$ & 1.12 & 0.82 & 6.57 \\
\hline $41-45$ & 76 & 304 & $\begin{array}{l}\text { yes } \\
\text { no }\end{array}$ & $\begin{array}{l}2.605 \\
2.597\end{array}$ & $\begin{array}{l}2.28-2.90 \\
2.12-2.72\end{array}$ & $\begin{array}{l}0.62 \\
0.60\end{array}$ & $2.60^{b}$ & 1.21 & 0.82 & 8.33 \\
\hline $46-50$ & 66 & 264 & $\begin{array}{l}\text { yes } \\
\text { no }\end{array}$ & $\begin{array}{l}2.825 \\
2.895\end{array}$ & $\begin{array}{l}2.56-3.09 \\
2.59-3.19\end{array}$ & $\begin{array}{l}0.53 \\
0.60\end{array}$ & $2.86^{c}$ & 1.59 & 0.82 & 8.58 \\
\hline $51-55$ & 56 & 224 & $\begin{array}{l}\text { yes } \\
\text { no }\end{array}$ & $\begin{array}{l}2.957 \\
2.782\end{array}$ & $\begin{array}{l}2.50-3.41 \\
2.35-3.20\end{array}$ & $\begin{array}{l}0.91 \\
0.85\end{array}$ & $2.87^{\mathrm{c}}$ & 0.97 & 0.96 & 12.48 \\
\hline $56-60$ & 52 & 208 & $\begin{array}{l}\text { yes } \\
\text { no }\end{array}$ & $\begin{array}{l}2.962 \\
2.783\end{array}$ & $\begin{array}{l}2.70-3.34 \\
2.69-3.25\end{array}$ & $\begin{array}{l}0.64 \\
0.56\end{array}$ & $2.87^{c}$ & 0.92 & 0.96 & 5.93 \\
\hline $61-65$ & 42 & 168 & $\begin{array}{l}\text { yes } \\
\text { no }\end{array}$ & $\begin{array}{l}2.783 \\
2.887\end{array}$ & $\begin{array}{l}2.51-2.95 \\
2.60-3.28\end{array}$ & $\begin{array}{l}0.44 \\
0.68\end{array}$ & $2.88^{c}$ & 0.95 & 0.97 & 5.78 \\
\hline $66-70$ & 30 & 120 & $\begin{array}{l}\text { yes } \\
\text { no }\end{array}$ & $\begin{array}{l}2.980 \\
2.966\end{array}$ & $\begin{array}{l}2.17-3.76 \\
2.56-3.31\end{array}$ & $\begin{array}{l}1.59 \\
0.75\end{array}$ & $2.97^{c}$ & 1.43 & 0.98 & 9.6 \\
\hline 71 plus & 18 & 72 & $\begin{array}{l}\text { yes } \\
\text { no }\end{array}$ & $\begin{array}{l}2.935 \\
2.901\end{array}$ & $\begin{array}{l}2.00-3.87 \\
1.89-3.91\end{array}$ & $\begin{array}{l}1.87 \\
2.02\end{array}$ & $2.92^{\mathrm{C}}$ & 1.40 & 1.12 & 6.88 \\
\hline total & $\sum 470$ & $\sum 1880$ & - & - & & & $\begin{array}{c}2.63 \\
\text { (weighted } \\
\text { mean) }\end{array}$ & & & \\
\hline
\end{tabular}

Table 5. Pooled gender-related distances CEJ-alveolar bone crest in the matching pairs of RCF and n-RCF teeth. Both intra-gender differences and inter-gender differences are shown and analyzed. Values of men were significantly higher compared to women $(p<0.0001)$. Different superscript letters indicate statistical significance $(p<0.05)$.

\begin{tabular}{|c|c|c|c|c|c|c|c|c|c|c|}
\hline Gender & $\begin{array}{l}\text { No of } \\
\text { Teeth }\end{array}$ & Age & RCF & & Mesial & Distal & $\begin{array}{l}\text { Lingual/ } \\
\text { Palatal }\end{array}$ & Buccal & Mean & Pooled Mean \\
\hline \multirow[t]{3}{*}{ men } & 94 & \multirow{5}{*}{$50.03 \pm 10.56$} & \multirow[t]{3}{*}{ yes } & mean $\pm \mathrm{sd}$ & $2.68 \pm 1.13$ & $2.77 \pm 1.50$ & $2.81 \pm 1.31$ & $2.74 \pm 1.25$ & $2.74 \pm 1.35$ & \multirow{6}{*}{$\begin{array}{c}2.73^{\mathrm{a}} \pm 1.25 \\
2.60-2.91 \\
0.31\end{array}$} \\
\hline & & & & $95 \%$ CI & $2.33-2.82$ & $2.56-3.23$ & $2.65-3.24$ & $2.38-2.91$ & $2.53-3.01$ & \\
\hline & & & & range & 0.49 & 0.67 & 0.59 & 0.53 & 0.48 & \\
\hline \multirow[t]{2}{*}{ men } & 94 & & \multirow[t]{2}{*}{ no } & $\begin{array}{c}\text { mean } \pm \text { sd } \\
95 \% \mathrm{CI}\end{array}$ & $\begin{array}{c}2.67 \pm 1.12 \\
2.40-2.95\end{array}$ & $\begin{array}{c}2.73 \pm 1.38 \\
2.50-2.97\end{array}$ & $\begin{array}{c}2.76 \pm 1.29 \\
2.55-3.01\end{array}$ & $\begin{array}{c}2.75 \pm 1.18 \\
2.56-3.06\end{array}$ & $\begin{array}{c}2.72 \pm 1.16 \\
2.55-2.94\end{array}$ & \\
\hline & & & & range & 0.45 & 0.47 & 0.46 & 0.50 & 0.39 & \\
\hline \multicolumn{3}{|l|}{ men } & \multicolumn{2}{|r|}{$p$-value } & 0.848 & 0.648 & 0.494 & 0.851 & 0.718 & \\
\hline \multirow[t]{3}{*}{ female } & \multirow[t]{3}{*}{141} & \multirow{5}{*}{$50.39 \pm 11.43$} & \multirow[t]{3}{*}{ yes } & mean $\pm \mathrm{sd}$ & $2.59 \pm 1.41$ & $2.62 \pm 1.10$ & $2.49 \pm 1.03$ & $2.49 \pm 1.03$ & $2.54 \pm 1.18$ & \multirow{6}{*}{$\begin{array}{c}2.53^{\mathrm{b}} \pm 1.17 \\
2.43-2.63 \\
0.20\end{array}$} \\
\hline & & & & $95 \%$ CI & $2.30-2.64$ & $2.33-2.73$ & $2.43-2.79$ & $2.35-2.69$ & $2.39-2.68$ & \\
\hline & & & & range & 0.34 & 0.40 & 0.36 & 0.34 & 0.29 & \\
\hline \multirow[t]{2}{*}{ female } & 141 & & no & $\begin{array}{c}\text { mean } \pm \mathrm{sd} \\
95 \% \mathrm{CI}\end{array}$ & $\begin{array}{c}2.43 \pm 1.17 \\
2.24-2.62\end{array}$ & $\begin{array}{c}2.56 \pm 1.30 \\
2.37-2.79\end{array}$ & $\begin{array}{c}2.61 \pm 1.10 \\
2.47-2.82\end{array}$ & $\begin{array}{c}2.45 \pm 1.04 \\
2.29-2.63\end{array}$ & $\begin{array}{c}2.51 \pm 1.16 \\
2.38-2.68\end{array}$ & \\
\hline & & & & range & 0.38 & 0.42 & 0.35 & 0.34 & 0.30 & \\
\hline female & & & & $p$-value & 0.519 & 0.566 & 0.85 & 0.629 & 0.802 & \\
\hline total & 235 & & & $p$-value & & & & & & $<0.00001$ \\
\hline
\end{tabular}




\subsection{Pooled Data (Overall Bone Level of Teeth Examined: RCF and Non-RCF Teeth)}

In general, patients older than 41 years showed lower bone levels in the matching pairs compared to younger patients independent of the absence or presence of a root canal filling $(p<0.05)$. Bone level in the maxilla $(2.74 \pm 1.48 \mathrm{~mm})$ was significantly lower compared to the mandible $(2.50 \pm 1.41 \mathrm{~mm})$ in both groups $(\mathrm{RCF} / \mathrm{n}-\mathrm{RCF})(p<0.001)$. Pooled ABClevels (non-RCF and RCF teeth) in men were significantly lower than in women $(p<0.05)$ (Table 5).

\section{Discussion}

The results of this cross-sectional observational analysis revealed no significant difference in ABC-levels between root canal filled teeth and the untreated counterparts in matching pairs in the same individual regardless of age at the time of examination, location/type of tooth and gender. Hence, the null-hypothesis was maintained.

\subsection{CBCT-Analysis}

In the present study, the results were exclusively based on measuring of the distance between the CEJ or a restauration at the level of the CEJ to the alveolar bone crest (ABC) by linear measurements in $\mathrm{CBCT}$ data. Thus, the study only investigated radiographic findings representing a momentary assessment providing no information about medical history of patients, previous history of teeth (i.e., orthodontic treatment) or even the progression of periodontitis. The study did not report bone loss, which is defined by degradation of bone over a period of time, but only described the bone level. No clinical parameters like the well-accepted surrogates assessing periodontal inflammation like bleeding on probing (BoP), or pocket depths (PD) were assessed and no conventional diagnosis and grading of periodontitis was performed. The study must be regarded as a radiographically comparative observational cross sectional study evaluating a possible association between a root canal filling and the corresponding alveolar bone crest level. This may be a limitation of the study but at the same time it represents a strength, because radiographic measurements are not affected by clinical parameters that may also have an impact on the accuracy and reliability of periodontal probing-influenced by numerous factors like periodontal health, probing force, type of periodontal probe, and probing site [21]. However, the prevalence of periodontal disease based on alveolar bone loss or alveolar bone level can be accurately and reliably evaluated even from non-standardized radiographs $[22,23]$ independent of numerous accompanying and influencing factors like the thickness, width, and angulation of the alveolar crest; thickness of lingual and facial alveolar bone plates; presence of fenestration and dehiscence; tooth alignment in the jaw; tooth and root trunk anatomy; tooth position within the alveolar processus; proximity with another tooth surface [24].

Despite the inherent bias in the selected cohort-individuals were subjected to CBCT analysis because of special needs and may be expected to have better health awareness than the general population - the use of CBCT in the present study should overcome the limitations of the two-dimensional intraoral radiographs with its superimposing artefacts due to the summation of adjacent structures or the distortions caused by different angulations of the central X-ray may influence the linear radiographic measurement of the distance CEJ to $A B C$ [20]. In general, intraoral radiographs tend to underestimate the extent of alveolar bone loss as compared to intrasurgical measurements [19,25]. Similarly, also CBCT analysis may underestimate the bone loss compared to clinical situations [26]. In contrast to this finding, it may be speculated that thin cortical bone margins (often the labial/buccal margins) are difficult to assess in the presence of artefacts. Hence, the bone level may also be underestimated (or a possible bone loss overestimated) [27]. Characteristically CBCT-associated limitations are scattering and moving artefacts or beam hardening [28]. The realistically achievable spatial resolution for images offering no visible blurring or moving artefacts is about $0.25-0.5 \mathrm{~mm}$ in-vivo [29]. Nevertheless, CBCT analysis is a reliable diagnostic tool for assessing bone level, and thus also allows appropriate periodontal treatment planning, as 
actual bone level correlates with the clinical situation well $[15,17,30,31]$. Even its suitability for assessing the cemento-enamel junction of teeth under clinical conditions has been proven [32]. However, CBCT analysis does not represent the golden standard in routine radiographic examination of patients affected with periodontal diseases. This also applies to endodontic diagnostics, with CBCT examinations suggested only for specific indications, when clinical examination and conventional imaging modalities are not conclusive [33-35].

\subsection{ABC-Level in Root Canal-Treated Teeth-General Aspects/Prognosis}

Root canal-treated teeth were often replaced by dental implants due to a perceived better success rate, often justified by a lack of conclusive evidence for the favorable long-term prognosis of root canal-treated teeth [36]. In combination with financial considerations, this may favor patients' and clinicians' decision for implants instead of endodontic treatment. However, implant survival rates definitively do not exceed those of compromised but adequately root canal-treated teeth [37]. It is well established that root canal treatment is a successful and reliable therapy that can remain teeth functional and healthy for even more than 20 years [38,39].

Periodontal health is claimed to be a prognostic determinant of the outcome of root canal-treated teeth. An increased risk of tooth loss of such teeth associated with the diagnosis of periodontitis has been documented [40]. Additionally, in the presence of apical periodontitis an increased pocket depth, faster attachment loss [10] and a less favorable outcome of non-surgical periodontal treatment is described, also [41]. Hence, the periodontal status of the teeth was not an inclusion/exclusion criterion in the present study but teeth with periapical lesions or furcal bone loss were excluded to avoid a biased evaluation due to a potentially inadequate root canal treatment, because it is well known that RCF-teeth are significantly more often associated with apical periodontitis compared to n-RCF-teeth. In a recently published systematic review, the prevalence of apical periodontitis in RCFteeth is reported to be over $40 \%$ [42]. Additionally, it has been shown that teeth with periapical pathologies in patients suffering from periodontitis have a threefold increase in bone loss than teeth without signs of periapical pathologies [10,40]. However, contrarily no significant correlation between endodontic conditions and the marginal bone levels were reported [6]. In order to focus exclusively on the influence of root canal fillings, the inclusion criteria were chosen very strictly and only comparable matching pairs in an individual were selected. This was done to prevent other factors from outweighing the target parameter. Thus, all factors associated to restorative aspects violating the biological width and not directly correlated to the endodontic treatment itself were excluded.

The exclusion of apical periodontitis could be considered a major limitation. However, radiographically evaluation does not allow to judge whether a visible apical periodontitis is in remission or in progression. The first would mean success and the latter would represent a failure in endodontic treatment outcome. Additionally, it is impossible to determine the reason for apical periodontitis retrospectively. Despite the finding of Petersson et al. [43], that the number of healed periapical lesions was equal to the number of newly developed lesions in a defined period of time, only teeth that met the inclusion criteria were evaluated concerning the $\mathrm{ABC}$ levels in order to solely investigate root canal filling as parameter and avoid a biased evaluation. Nevertheless, even when such strict criteria are applied, it remains unclear whether one of the teeth examined will develop apical periodontitis or not. Apical periodontitis was diagnosed when either disruption of the lamina dura was noted at the apex with a hypodense area exceeding $0.5 \mathrm{~mm}$ or the periodontal ligament showed more than twice width and was not parallel to the root contour $[44,45]$.

A possible malocclusion according to Angle's classification system as well as orthodontic treatment in previous history as an influencing factor on the ABC level of the examined teeth could not be determined, too. Nonetheless, due to the assessment in the same individual (matching pairs) this aspect may have a negligible impact because of assumed symmetry of orthodontic forces. 
The present findings corroborate that a root canal filling per se had no impact on the marginal periodontal conditions at least in single rooted teeth [6]. This observation is also valid for multi-rooted teeth without apical periodontitis or furcal defects, because no significant differences concerning tooth types (anterior teeth, premolars, molars) occurred in terms of alveolar bone level between the groups (RCF vs. n-RCF), which is also evident from the pairwise comparison of the values obtained (Figure 2). Therefore, the longevity of teeth may not primarily depend on the presence of an adequately performed root canal treatment. The causal effect chain does not follow the following sequence: RCF $\rightarrow$ reduced bone level $\rightarrow$ extraction. Moreover, numerous other initially assessed periodontal parameters influence the risk of tooth loss, e.g., probing depth, furcation involvement, mobility, percent bone loss, untreated parafunctional habits, and smoking led to an increased risk of tooth loss [46].

Apart from that, a reduced bone level itself is not necessarily associated with increased pocket probing depth - the most valuable predictor for long-term tooth survival [47]. Additionally, the destruction of clinical attachment does not strictly correlate with bone loss in extent and over time. Bone levels in the present study may only indicate the presence or absence of attachment that tends to precede the radiographic crestal bone loss during phases of increased activity in patients with periodontal disease [48]. Machtei et al. corroborated this finding as changes in clinical attachment loss and radiographic bone level occur time-delayed but tend to level off in the end [49]. Hence, it was impossible to extrapolate the current clinical attachment level of the patients by the evaluated parameters. The focus was solely set on the difference between teeth with or without a root canal filling.

\subsection{ABC-Level-Location, Age and Gender Related Aspects}

In general, reduced $\mathrm{ABC}$-levels indicating bone loss was significantly higher in the maxilla than in the mandible, regardless of the teeth being root canal treated or not. This may be explained by a significantly higher turnover rate in the mandible and bone density compared to the maxilla $[50,51]$. The ratio of compact to trabecular bone in the maxilla is about $10 \%$ to $90 \%$ while the mandible's ratio is about $80 \%$ to $20 \%$ [52]. An explanation for generally increased bone loss in the alveolar process of the maxilla could be that trabecular bone is more prone to resorption than cortical bone [53].

It should be noted that the present study was conducted as a cross-over study in a selected population and thus included a cross-section of all age groups and any severity of periodontal disease. Thus, the mean values of $\mathrm{ABC}$-level exceeded the physiological height of about 1.5-2 mm. Castro et al. investigated mean values in a range of $1.4 \pm 0.35 \mathrm{~mm}$ [54]. Due to the age of the included patients of this cross-sectional observational study (mean $50.21 \mathrm{y} \pm 11.10)$, the presence of bone loss is indispensable. The "German dental survey (DMS-5)" shows that periodontitis affects the majority of the ageing population [55]. Whereas approximately every second person $(51.6 \%$ ) in the age of 35-44 is affected by periodontal disease, about $2 / 3(64.6 \%$ ) of elderly people (65-74 years) and up to $90 \%$ in the old population (75-100 years) are affected.

Statistically significant differences regarding bone loss overall (pooled values of RCF and n-RCF teeth) have been found from the age of 41 years upwards. Several epidemiological studies confirm that the loss of periodontal attachment and/or alveolar bone level is associated with increasing age [56-61]. The markedly reduced ABC-level in men compared to women signifies a possible gender related pathogenesis in periodontal disease and corroborates current reviews [62,63].

\subsection{Final Appraisal}

It seems intuitive to think about infinite correlations within the human body (i.e., root canal treatment and the crestal bone level, but this assumption is dependent on several known and unknown confounders that are impossible to addressed within the study design [64]. It must be stated that association does not mean causation. The study did not aim to find a causality between periodontal disease and the bone level of root 
canal treated teeth but was rather designed as an observational study. In conclusion, the authors are aware of the multi-causal, complex polymorphic process of alveolar bone crest loss and therefore the bone level in adults and further future research evaluating the impact of root canal treatment and other factors (e.g., malocclusion or previous orthodontic treatment) on the longevity of functioning teeth in an ageing population is needed using both radiographic and clinical assessments of the corresponding parameters.

\section{Conclusions}

Within the limitations of the present comparative observational study based on CBCTdata, it can be concluded that a root canal filling per se did not affect the crestal bone level of teeth irrespective of the periodontal status. Thus, with regard to the demographic change, root canal treatment represents an essential pillar for long-term tooth preservation. However, the overall bone level seems to decrease with age and is significantly more pronounced in the maxilla than in the mandible. Men tend to have lower alveolar-bonecrest levels compared to women.

Supplementary Materials: The following is available online at https://www.mdpi.com/article/10 $.3390 /$ app 11188583 / s1 STROBE Statement, STROBE State-ment—checklist of items that should be included in reports of observational studies.

Author Contributions: Conceptualization, M.L., E.S. and S.B.; methodology, D.D., E.S. and S.B.; software, M.L.; validation, M.L. and S.B.; formal analysis, M.L. and S.B.; investigation, M.L. and S.B.; resources, S.B.; data curation, M.L.; writing—original draft preparation, M.L. and S.B.; writingreview and editing, E.S. and D.D.; visualization, E.S.; supervision, E.S. All authors have read and agreed to the published version of the manuscript.

Funding: The authors received no funding for this work.

Institutional Review Board Statement: The study was carried out in accordance with the ethical principles of the current revision of the "Declaration of Helsinki". Referral of the patients for diagnosis, consulting or treatment allowed access to the images. CBCT data had no potentially identifying marks/features and no patient identifiers in the images. Thus, the data of this retrospective, observational study were completely anonymized-only origin, gender and age at the time of examination were noted for statistical analysis when data were exported with the Planmeca Romexis 6.0 (Planmeca, Helsinki, Finland) for subsequent analysis. Data export allowed anonymization by activating the according check mark in the software. Therefore, no approval by the local ethics committee was required.

Informed Consent Statement: Not applicable.

Data Availability Statement: The datasets used and/or analyzed during the current study are available from the correspon-ding author on reasonable request.

Conflicts of Interest: The authors declare no conflict of interest.

\section{References}

1. Dammaschke, T.; Witt, M.; Ott, K.; Schäfer, E. Scanning electron microscopic investigation of incidence, location, and size of accessory foramina in primary and permanent molars. Quintessence Int. 2004, 35, 699-705.

2. Kerekes, K.; Olsen, I. Similarities in the microfloras of root canals and deep periodontal pockets. Endod Dent Traumatol. 1990, 6, 1-5. Available online: https:/ / pubmed.ncbi.nlm.nih.gov/2202588/ (accessed on 25 March 2021). [CrossRef]

3. Sundqvist, G. Taxonomy, ecology, and pathogenicity of the root canal flora. Oral Surg. Oral Med. Oral Pathol. 1994, 78, 522-530. Available online: https:/ / pubmed.ncbi.nlm.nih.gov/7800383/ (accessed on 25 March 2021). [CrossRef]

4. Zehnder, M.; Gold, S.I.; Hasselgren, G. Pathologic interactions in pulpal and periodontal tissues. J. Clin. Periodontol. 2002, 29, 663-671. [CrossRef]

5. Miyashita, H.; Bergenholtz, G.; Gröndohl, K.; Wennström, J.L. Impact of Endodontic Conditions on Marginal Bone Loss. J. Periodontol. 1998, 69, 158-164. [CrossRef] [PubMed]

6. Bertl, K.; Suljkanovic, N.; Suljkanovic, L.; Lettner, S.; Esfandeyari, A.; Moritz, A.; Stavropoulos, A.; Bruckmann, C. A root canal filling per se does not have a significant negative effect on the marginal periodontium. J. Clin. Periodontol. 2015, 42, 520-529. [CrossRef] 
7. Adyani-Fard, D.; Kim, T.-S.; Eickholz, P. Interproximal bone loss at contra-lateral teeth with and without root canal filling in periodontitis patients. J. Clin. Periodontol. 2010, 38, 269-275. [CrossRef]

8. Rodriguez, F.-R.; Paganoni, N.; Eickholz, P.; Weiger, R.; Walter, C. Presence of root canal treatment has no influence on periodontal bone loss. Clin. Oral Investig. 2017, 21, 2741-2748. [CrossRef] [PubMed]

9. Timmerman, M.; Van Der Weijden, G. Bone level around endodontically treated teeth in periodontitis patients. J. Clin. Periodontol. 2006, 33, 620-625. [CrossRef] [PubMed]

10. Jansson, L.; Ehnevid, H.; Lindskog, S.; Blomlof, L. The influence of endodontic infection on progression of marginal bone loss in periodontitis. J. Clin. Periodontol. 1995, 22, 729-734. [CrossRef] [PubMed]

11. Jansson, L. Relationship between apical periodontitis and marginal bone loss at individual level from a general population. Int. Dent. J. 2015, 65, 71-76. [CrossRef] [PubMed]

12. Scarfe, W.C.; Farman, A.G.; Sukovic, P. Clinical applications of cone-beam computed tomography in dental practice. J. Can. Dent. Assoc. 2006, 72, 75-80. [PubMed]

13. Raichur, P.S.; Setty, S.B.; Thakur, S.L.; Naikmasur, V.G. Comparison of Radiovisiography and Digital volume tomography to direct surgical measurements in the detection of infrabony defects. J. Clin. Exp. Dent. 2012, 4, e43-e47. Available online: http:/ / www.ncbi.nlm.nih.gov/pubmed/24558524 (accessed on 5 February 2019). [CrossRef]

14. Vandenberghe, B.; Jacobs, R.; Yang, J. Detection of periodontal bone loss using digital intraoral and cone beam computed to-mography images: An in vitro assessment of bony and/or infrabony defects. Dentomaxillofac. Radiol. 2008, 37, 252-260. [CrossRef] [PubMed]

15. Bagis, N.; Kolsuz, M.E.; Kursun, S.; Orhan, K. Comparison of intraoral radiography and cone-beam computed tomography for the detection of periodontal defects: An in vitro study. BMC Oral Health 2015, 15, 1-8. [CrossRef] [PubMed]

16. Menezes, C.C.; Janson, G.; Massaro, C.; Cambiaghi, L.; Garib, D.G. Precision, reproducibility, and accuracy of bone crest level measurements of CBCT cross sections using different resolutions. Angle Orthod. 2015, 86, 535-542. Available online: https: / / pubmed.ncbi.nlm.nih.gov/26488463/ (accessed on 25 March 2021). [CrossRef] [PubMed]

17. Haas, L.F.; Zimmermann, G.S.; De Luca Canto, G.; Flores-Mir, C.; Corrêa, M. Precision of cone beam CT to assess periodontal bone defects: A systematic review and meta-analysis. Dentomaxillofac. Radiol. Br. Inst. Radiol. 2018, 47. Available online: https: / / pubmed.ncbi.nlm.nih.gov/28869397/ (accessed on 25 March 2021). [CrossRef] [PubMed]

18. Kojima, K.; Inamoto, K.; Nagamatsu, K.; Hara, A.; Nakata, K.; Morita, I.; Nakagaki, H.; Nakamura, H. Success rate of endodontic treatment of teeth with vital and nonvital pulps. A meta-analysis. Oral Surg. Oral Med. Oral Pathol. Oral Radiol. Endodontol. 2004, 97, 95-99. [CrossRef]

19. Eickholz, P.; Kim, T.-S.; Benn, D.K.; Staehle, H.J. Validity of radiographic measurement of interproximal bone loss. Oral Surg. Oral Med. Oral Pathol. Oral Radiol. Endodontol. 1998, 85, 99-106. [CrossRef]

20. Hadzik, J.; Kubasiewicz-Ross, P.; Nawrot-Hadzik, I.; Gedrange, T.; Pitułaj, A.; Dominiak, M. Short (6 mm) and Regular Dental Implants in the Posterior Maxilla-7-Years Follow-up Study. J. Clin. Med. 2021, 10, 940. Available online: https: / /www.mdpi.com/2077-0383/10/5/940 (accessed on 25 March 2021). [CrossRef]

21. Khan, S.; Cabanilla, L.L. Periodontal probing depth measurement: A review. Compend. Contin. Educ. Dent. 2009, $30,12-36$.

22. Eickholz, P.; Riess, T.; Lenhard, M.; Hassfeld, S.; Staehle, H.J. Digital radiography of interproximal bone loss; validity of different filters. J. Clin. Periodontol. 1999, 26, 294-300. [CrossRef]

23. Merchant, A.T.; Pitiphat, W.; Parker, J.; Joshipura, K.; Kellerman, M.; Douglass, C.W. Can nonstandardized bitewing radiographs be used to assess the presence of alveolar bone loss in epidemiologic studies? Community Dent. Oral Epidemiol. 2004, 32, 271-276. [CrossRef]

24. Zaki, H.A.M.; Hoffmann, K.R.; Hausmann, E.; Scannapieco, F.A. Is Radiologic Assessment of Alveolar Crest Height Useful to Monitor Periodontal Disease Activity? Dent. Clin. N. Am. 2015, 59, 859-872. [CrossRef]

25. Tonetti, M.S.; Prato, G.P.; Williams, R.C.; Cortellini, P. Periodontal Regeneration of Human Infrabony Defects. III. Diagnostic Strategies to Detect Bone Gain. J. Periodontol. 1993, 64, 269-277. [CrossRef]

26. Yang, J.; Li, X.; Duan, D.; Bai, L.; Zhao, L.; Xu, Y. Cone-beam computed tomography performance in measuring periodontal bone loss. J. Oral Sci. 2019, 61, 61-66. [CrossRef] [PubMed]

27. Leung, C.C.; Palomo, L.; Griffith, R.; Hans, M.G. Accuracy and reliability of cone-beam computed tomography for measuring alveolar bone height and detecting bony dehiscences and fenestrations. Am. J. Orthod. Dentofac. Orthop. 2010, 137, S109-S119. Available online: http:/ / www.ajodo.org/article/S0889540610000302/fulltext (accessed on 25 March 2021). [CrossRef] [PubMed]

28. Schulze, R.; Heil, U.; Gross, D.; Bruellmann, D.D.; Dranischnikow, E.; Schwanecke, U.; Schoemer, E. Artefacts in CBCT: A review. Dentomaxillofac. Radiol. 2011, 40, 265-273. [CrossRef] [PubMed]

29. Brüllmann, D.; Schulze, R. Spatial resolution in CBCT machines for dental/maxillofacial applications-what do we know today? Dentomaxillofac. Radiol. 2015, 44, 20140204. [CrossRef]

30. Abdinian, M.; Yaghini, J.; Jazi, L. Comparison of intraoral digital radiography and cone-beam computed tomography in the measurement of periodontal bone defects. Dent. Med Probl. 2020, 57, 269-273. [CrossRef]

31. Assiri, H.; Dawasaz, A.A.; AlAhmari, A.; Asiri, Z. Cone beam computed tomography (CBCT) in periodontal diseases: A Systematic review based on the efficacy model. BMC Oral Health. 2020, 20, 1-15. [CrossRef]

32. Srebrzyńska-Witek, A.; Koszowski, R.; Różyło-Kalinowska, I.; Piskórz, M. CBCT for estimation of the cemento-enamel junction and crestal bone of anterior teeth. Open Med. 2020, 15, 774-781. [CrossRef] 
33. Bhatt, M.; Coil, J.; Chehroudi, B.; Esteves, A.; Aleksejuniene, J.; Macdonald, D. Clinical decision-making and importance of the AAE/AAOMR position statement for CBCT examination in endodontic cases. Int. Endod. J. 2020, 54, 26-37. [CrossRef]

34. Patel, S.; Brown, J.; Semper, M.; Abella, F.; Mannocci, F. European Society of Endodontology position statement: Use of cone beam computed tomography in Endodontics: European Society of Endodontology (ESE). Int. Endod. J. 2019, 52, 1675-1678. Available online: https:/ / pubmed.ncbi.nlm.nih.gov/31301231/ (accessed on 9 September 2021). [CrossRef] [PubMed]

35. Fayad, M.I.; Nair, M.; Levin, M.D.; Benavides, E.; Rubinstein, R.A.; Barghan, S.; Hirschberg, C.S.; Ruprecht, A. AAE and AAOMR Joint Position Statement Use of Cone Beam Computed Tomography in Endodontics. Oral Surg. Oral Med. Oral Pathol. Oral Radiol. 2015, 120, 508-512. Available online: https://pubmed.ncbi.nlm.nih.gov/26346911/ (accessed on 9 September 2021). [CrossRef] [PubMed]

36. Iqbal, M.; Kim, S. For teeth requiring endodontic treatment, what are the differences in outcomes of restored endodontically treated teeth compared to implant restorations? Br. Dent. J. 2007, 203, 333. Available online: https: / / europepmc.org/ (accessed on 25 March 2021).

37. Levin, L.; Halperin-Sternfeld, M. Tooth preservation or implant placement: A systematic Review of long-term tooth and implant survival rates. J. Am. Dent. Assoc. 2013, 144, 1119-1133. Available online: https://pubmed.ncbi.nlm.nih.gov/24080928/ (accessed on 25 March 2021). [CrossRef] [PubMed]

38. Prati, C.; Pirani, C.; Zamparini, F.; Gatto, M.R.; Gandolfi, M.G. A 20-year historical prospective cohort study of root canal treatments. A Multilevel analysis. Int. Endod. J. 2018, 51, 955-968. [CrossRef] [PubMed]

39. Mareschi, P.; Taschieri, S.; Corbella, S. Long-Term Follow-Up of Nonsurgical Endodontic Treatments Performed by One Specialist: A Retrospective Cohort Study about Tooth Survival and Treatment Success. Int. J. Dent. 2020, 2020, 1-8. [CrossRef] [PubMed]

40. Khalighinejad, N.; Aminoshariae, A.; Kulild, J.C.; Wang, J.; Mickel, A. The Influence of Periodontal Status on Endodontically Treated Teeth: 9-year Survival Analysis. J. Endod. 2017, 43, 1781-1785. Available online: https://pubmed.ncbi.nlm.nih.gov/2882 2565/41. (accessed on 25 March 2021). [CrossRef] [PubMed]

41. Ehnevid, H.; Jansson, L.; Lindskog, S.; Blomlof, L. Periodontal healing in teeth with periapical lesions. A clinical retrospective study. J. Clin. Periodontol. 1993, 20, 254-258. [CrossRef] [PubMed]

42. Jakovljevic, A.; Nikolic, N.; Jacimovic, J.; Pavlovic, O.; Milicic, B.; Beljic-Ivanovic, K.; Miletic, M.; Andric, M.; Milasin, J. Prevalence of Apical Periodontitis and Conventional Nonsurgical Root Canal Treatment in General Adult Population: An Updated Systematic Review and Meta-analysis of Cross-sectional Studies Published between 2012 and 2020. J. Endod. 2020, 46, 1371-1386.e8. Available online: https:/ / pubmed.ncbi.nlm.nih.gov/32673634/ (accessed on 25 March 2021). [CrossRef] [PubMed]

43. Petersson, K.; Hakansson, R.; Olsson, B.; Wennberg, A. Follow-up study of endodontic status in an adult Swedish population. Dent. Traumatol. 1991, 7, 221-225. [CrossRef] [PubMed]

44. Abella, F.; Patel, S.; Duran-Sindreu, F.; Mercade, M.; Bueno, R.; Roig, M. Evaluating the Periapical Status of Teeth with Irreversible Pulpitis by Using Cone-beam Computed Tomography Scanning and Periapical Radiographs. J. Endod. 2012, 38, 1588-1591. [CrossRef] [PubMed]

45. Zhang, M.-M.; Liang, Y.-H.; Gao, X.-J.; Jiang, L.; van der Sluis, L.; Wu, M.-K. Management of Apical Periodontitis: Healing of Post-treatment Periapical Lesions Present 1 Year after Endodontic Treatment. J. Endod. 2015, 41, 1020-1025. [CrossRef] [PubMed]

46. McGuire, M.K.; Nunn, M.E. Prognosis Versus Actual Outcome. III. The Effectiveness of Clinical Parameters in Accurately Predicting Tooth Survival. J. Periodontol. 1996, 67, 666-674. Available online: https://pubmed.ncbi.nlm.nih.gov/8832477/ (accessed on 25 March 2021). [CrossRef]

47. Saminsky, M.; Halperin-Sternfeld, M.; Machtei, E.E.; Horwitz, J. Variables affecting tooth survival and changes in probing depth: A long-term follow-up of periodontitis patients. J. Clin. Periodontol. 2015, 42, 513-519. [CrossRef]

48. Goodson, J.M.; Haffajee, A.D.; Socransky, S.S. The relationship between attachment level loss and alveolar bone loss. J. Clin. Periodontol. 1984, 11, 348-359. [CrossRef] [PubMed]

49. Machtei, E.E.; Hausmann, E.; Grossi, S.G.; Dunford, R.; Genco, R.J. The relationship between radiographic and clinical changes in the periodontium. J. Periodontal. Res. 1997, 32, 661-666. [CrossRef]

50. Huja, S.S.; Fernandez, S.A.; Hill, K.J.; Li, Y. Remodeling dynamics in the alveolar process in skeletally mature dogs. Anat. Rec. Part A: Discov. Mol. Cell. Evol. Biol. 2006, 288A, 1243-1249. [CrossRef]

51. Huja, S.S.; Beck, F.M. Bone Remodeling in Maxilla, Mandible, and Femur of Young Dogs. Anat. Rec. Adv. Integr. Anat. Evol. Biol. 2007, 291, 1-5. [CrossRef]

52. Von Wowern, N. Bone mass of mandibles. In vitro and in vivo analyses. Dan. Med. Bull. 1986, 33, 23-44. Available online: http:/ / www.ncbi.nlm.nih.gov/pubmed/3948537 (accessed on 6 February 2020).

53. Li, J.; Bao, Q.; Chen, S.; Liu, H.; Feng, J.; Qin, H.; Li, A.; Liu, D.; Shen, Y.; Zhao, Y.; et al. Different bone remodeling levels of trabecular and cortical bone in response to changes in Wnt/ $\beta$-catenin signaling in mice. J. Orthop. Res. 2016, 35, 812-819. [CrossRef] [PubMed]

54. Castro, L.O.; Castro, I.O.; De Alencar, A.H.G.; Valladares-Neto, J.; Estrela, C. Cone beam computed tomography evaluation of distance from cementoenamel junction to alveolar crest before and after nonextraction orthodontic treatment. Angle Orthod. 2015, 86, 543-549. [CrossRef] 
55. Jordan, R.A.; Micheelis, W.; Cholmakow-Bodechtel, C.; Hertrampf, K.; Hoffmann, T.; Hertrampf, K.; Füßl-Grünig, E.; Geyer, S.; Holtfreter, B.; Kocher, T.; et al. Fünfte Deutsche Mundgesundheitsstudie (DMS V); Institut Der Deutschen Zahnärzte (IDZ): Koln, Germany, 2016; Available online: https://www.idz.institute/fileadmin/Content/Publikationen-PDF/Bd_35-Fuenfte_Deutsche_ Mundgesundheitsstudie_DMS_V.pdf (accessed on 6 February 2020).

56. Papapanou, P.N.; Lindhe, J.; Sterrett, J.D.; Eneroth, L. Considerations on the contribution of ageing to loss of periodontal tissue support. J. Clin. Periodontol. 1991, 18, 611-615. [CrossRef]

57. Mack, F.; Mojon, P.; Budtz-Jorgensen, E.; Kocher, T.; Splieth, C.; Schwahn, C.; Bernhardt, O.; Gesch, D.; Kordass, B.; John, U.; et al. Caries and periodontal disease of the elderly in Pomerania, Germany: Results of the Study of Health in Pomerania. Gerodontology 2004, 21, 27-36. [CrossRef]

58. Eke, P.I.; Page, R.C.; Wei, L.; Thornton-Evans, G.; Genco, R.J. Update of the Case Definitions for Population-Based Surveillance of Periodontitis. J. Periodontol. 2012, 83, 1449-1454. [CrossRef] [PubMed]

59. Renvert, S.; Persson, R.E.; Persson, G.R. Tooth Loss and Periodontitis in Older Individuals: Results From the Swedish National Study on Aging and Care. J. Periodontol. 2013, 84, 1134-1144. [CrossRef] [PubMed]

60. Thomson, W.M.; Shearer, D.M.; Broadbent, J.; Page, L.F.; Poulton, R. The natural history of periodontal attachment loss during the third and fourth decades of life. J. Clin. Periodontol. 2013, 40, 672-680. [CrossRef]

61. López, R.; Smith, P.C.; Göstemeyer, G.; Schwendicke, F. Ageing, dental caries and periodontal diseases. J. Clin. Periodontol. 2017, 44, S145-S152. [CrossRef]

62. Shiau, H.J.; Reynolds, M.A. Sex Differences in Destructive Periodontal Disease: A Systematic Review. J. Periodontol. 2010, 81, 1379-1389. [CrossRef] [PubMed]

63. Eke, P.; Dye, B.; Wei, L.; Thornton-Evans, G.; Genco, R. Prevalence of Periodontitis in Adults in the United States: 2009 and 2010. J. Dent. Res. 2012, 91, 914-920. [CrossRef] [PubMed]

64. Bloomgarden, Z.T. Association is not causation, particularly with “adjustment". J. Diabetes 2014, 6, 195-196. [CrossRef] [PubMed] 